\title{
Business Intelligence Case Study: Hotel Taxes Receipts
}

\author{
Henry D. Crockett, Tarleton State University, USA
}

\begin{abstract}
This case is based upon consulting projects the author has conducted for both corporate and governmental groups. Many governmental agencies now provide large amounts of data for use by their constituents. It is very effective to use this live data in a classroom environment instead of that provided by textbooks and/or publishers. This case describes a process whereby the use of business intelligence in many forms could be used for the solution. The state of Texas Comptroller's office currently collects information concerning hotel taxes receipts that not only details remittances to both the state and local governments, they are also required to use the same data to predict the next years hotel tax receipts for use in a state budget. This case allows the professor to discuss or actually develop a solution. Since the data is provided in a rotating thirteen month cycle, solutions will never be numerically equivalent each time the course is taught.
\end{abstract}

Keywords: Business Intelligence Case Study; Information Systems Case Study

\section{OVERVIEW OF THE HOTEL TAXES RECEIPTS PROBLEM}

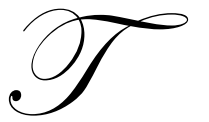

exas has had a Comptroller, who is the chief steward of finances, since the creation of a provisional government after the successful revolt from Mexico in 1835. The office was created by the provisional government of Texas and is included in each state constitution since the founding of Texas. The current state Constitution of Texas was enacted in 1878 and contains requirements of the Texas Comptroller in article 4 sections 1 and 23. The Comptroller's main duty is to collect all state taxes. The Comptroller is also responsible for the treasury, forecasting estimated revenues, and all of the accounting details required by Texas legislators. (Texas State Library and Archives Commission, 2005)

The Comptroller is currently responsible for collection and forecast of over 60 taxes, fees, and assessments including a hotel occupancy tax based on the taxible reciepts of Texas hotels. The Comptroller is also responsible for returning any city or county taxes based on taxable receipts. The taxes on room occupancy is based on rule $3.165(\mathrm{~b})$ and excluding charges not subject to tax as defined in rules 3.165(c), 3.161and 3.163. (Office of the Texas Comptroller, 2011). In the last several years Susan Combs, the current Comptroller, has noticed that the data collection for Texas Hotel tax based on room occupancy is capturing data that is below the quality required to provide an accurate forecast of room occupancy taxes in the future. The primary reason for the low accuracy of data is that these data are self-reported by the hotel owners on form "Texas Hotel Occupancy Tax Report" $(12-100)$ (Comptroller of Public accounts) are either incomplete or unreadable. There is also no state-mandated training in the correct process for completing and submitting their documentation. Because most of these reports are handwritten, even after the proper submission of data, often problems exist in transcribing the data from the form correctly. To increase the accuracy of the form the Comptroller's office also provides a web form which can be submitted electronically (Texas Hotel Occupancy Tax Forms). Each month the Comptroller's office allows owners to make data modifications to any data on a previously turned in $12-100$ through resubmission of backdatedforms. In most cases this means that the hotel owner either missed the deadline or that the previous months entry was reported incorrectly. The data collected using these paper forms is then entered into the system adding to the data which can be submitted electronically. The resulting data for the last 13 months is provided in comma-separated value (CSV file) format (Texas State Comptroler's Office, 2011). The layout of each CSV is shown in Table 1 below. 
Table 1. (Texas State Comptroler's Office, 2011)

\begin{tabular}{|l|c|l|}
\hline \multicolumn{1}{|c|}{ Columns } & Length & \multicolumn{1}{|c|}{ Field Description } \\
\hline $1-11$ & 11 & Taxpayer Number \\
\hline $14-63$ & 50 & Taxpayer Name \\
\hline $67-106$ & 40 & Taxpayer Address \\
\hline $110-129$ & 20 & Taxpayer City \\
\hline $133-134$ & 2 & Taxpayer State \\
\hline $138-142$ & 5 & Taxpayer Zip Code \\
\hline $145-147$ & 3 & Taxpayer County \\
\hline $149-153$ & 5 & Outlet Number \\
\hline $156-205$ & 50 & Location Name \\
\hline $209-248$ & 40 & Location Address \\
\hline $252-271$ & 20 & Location City \\
\hline $275-276$ & 2 & Location State \\
\hline $280-284$ & 5 & Location Zip Code \\
\hline $287-289$ & 3 & Location County \\
\hline $291-295$ & 5 & Location Room Capacity \\
\hline $297-309$ & 13 & Location Total Room Receipts (9999999999.99) \\
\hline $311-323$ & 13 & Location Taxable Receipts (9999999999.99) \\
\hline
\end{tabular}

To increase the accuracy of the forecast of the hotel occupancy taxes the Comptroller has found it necessary to develop a business intelligence(BI) application (Bhatia, 2010) (Raden, 2007). Due to the number of offices in the state comptroller's chain of command that will interact with the hotel taxes receipts BI application, the internal or external agency providing the solution will be required to interact with several different offices that fall within the state Texas state office of the Comptroller of Public accounts. According to the current strategic plan for the Comptroller's office the development will be outsourced to a qualified consultant since the agency does not have the required expertise in business intelligence. Once the needs have been determined and initial setup of a business intelligence solution have been completed the agency will recruit personnel with the required knowledge level to perform this function in-house (Texas Comptroller of Public Accounts, 2010)

\section{REQUIREMENTS}

As the qualified consultant selected through an RFP process you will be required to prepare both a report and a BI solution. All documents for your solution must be returned in electronic format. Reports should be submitted using Microsoft Word or Adobe Acrobat format. The following steps were detailed in the BI Project requirements:

1. In view of the data issues, data cleansing will be required before using it to develop the business intelligence data model. Download data from the state of Texas Comptroller's office in CSV format and show the process required to clean the data. The field layout is given in table 1 (Texas State Comptroler's Office, 2011). Part of this process will be to identify specific issues that you discover in the data and provide the Comptroller's office with any data failing your specifications.

2. Once the data is restructured, it must be modeled for online analytical processing (OLAP). As the Comptroller's office has hired you for your expertise, you will need to discuss multidimensional OLAP(MOLAP), relational OLAP (ROLAP), and hybrid OLAP(HOLAP) structures and choose the one you believe most fits its needs (A Model for Object Relationship OLAP, 2010). After choosing this structure you will then need to transform the data into the form required by your structure. If you choose MOLAP or HOLAP, you should also discuss the relative merits of Star data structures versus Snowflake.

3. Using the data from the first requirement in the structure from the second requirement develop a data warehouse (DW). Discuss possible benefits to the state Comptroller's office of maintaining a data warehouse to capture all 60+ taxes fees and assessments that it is required to collect and report.

4. The Texas State Comptroller's office requires that you present at least three alternative methods which could be used to provide the BI solution. Your solution should require the least amount of manual steps; a fully automated application would be preferred. The Comptroller also prefers that the results be available 
through Microsoft Internet Explorer web browser. Currently the Comptroller's office is a primarily Microsoft environment with access to Microsoft Office Professional Plus 2010, Microsoft SQL 2008 R2, and Microsoft SharePoint 2010.

5. Using the data developed in steps one and two, present all reports and graphs that are indicated in your solution. Texas State Comptroller's office will use your application to view changes in hotel tax receipts by month, quarter, county, city, and zip code.

\section{TEACHING NOTES} the author.

A comprehensive set of solutions using Microsoft SQL 2008 R2 and instructor guidance is available from

\section{AUTHOR INFORMATION}

Henry D Crockett, $\mathrm{PhD}$ is an associate professor of CIS at Tarleton State University. Tarleton State University, PO Box T - 0170, Stephenville, TX 76402. E-mail: Crockett@Tarleton.edu

\section{REFERENCES}

1. A Model for Object Relationship OLAP. (2010). International Journal on Artificial Intelligence Tools, 19(5), 551-595. doi:10.1142/S0218213010000327

2. Bhatia, R. (2010, March 30). Business Intelligence 2.0. Retrieved April 21, 2011, from Ezine @ rticles: http://ezinearticles.com/?Business-Intelligence-2.0\&id=4015979

3. Raden, N. (2007, February 1). Business Intelligence 2.0: Simpler, More Accessible, Inevitable. Retrieved April 21, 2011, from Intelligent Enterprise: http://www.informationweek.com/news/software/bi/197002610

4. Texas Comptroller of Public Accounts. (2010). Agency Strategic Plan for the Period 2011 - 2015 (Vols. Publication \# 96-361). Austin, Texas: Texas Comptroller of Public Accounts Budget and Internal Accounting. Retrieved February 8, 2012, from http://www.window.state.tx.us/taxbud/strategic/96-36110.pdf

5. Texas Comptroller of Public Accounts. (2011, Dec. 3). Retrieved from Window on State Government.: http://www.window.state.tx.us/

6. Texas Comptroller of Public Accounts. (2011, Dec. 4). Texas Hotel Occupancy Tax Report - Form 12-100. Retrieved from http://www.window.state.tx.us/taxinfo/taxforms/12-100.pdf

7. Texas Comptroller of Public accounts. (n.d.). Texas Hotel occupancy tax report.

8. Texas Hotel Occupancy Tax Forms. (n.d.). Retrieved from Window on State Government: http://www.window.state.tx.us/taxinfo/taxforms/12-forms.html

9. Texas State Comptroler's Office. (2011, 12 30). Tax Files. Retrieved from Window on State Government: http://www.window.state.tx.us/taxinfo/taxfiles.html

10. Texas State Library and Archives Commission. (2005, February 1). Texas Comptroller's Office: An Inventory of Comptroller's Office Organization Charts at the Texas State Archives, 1978-2005. Retrieved February 13, 2012, from http://www.lib.utexas.edu/taro/tslac/50015/50015-P.html 


\section{NOTES}

